The Dentition of Lambdotherium

Author(s): Ygnacio Bonillas

Source: Journal of Mammalogy, Vol. 17, No. 2 (May, 1936), pp. 139-142

Published by: American Society of Mammalogists

Stable URL: https://www.jstor.org/stable/1374188

Accessed: 18-11-2019 15:10 UTC

JSTOR is a not-for-profit service that helps scholars, researchers, and students discover, use, and build upon a wide range of content in a trusted digital archive. We use information technology and tools to increase productivity and facilitate new forms of scholarship. For more information about JSTOR, please contact support@jstor.org.

Your use of the JSTOR archive indicates your acceptance of the Terms \& Conditions of Use, available at https://about.jstor.org/terms

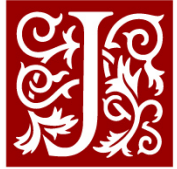

American Society of Mammalogists is collaborating with JSTOR to digitize, preserve and extend access to Journal of Mammalogy 


\section{THE DENTITION OF LAMBDOTHERIUM}

\section{By YGNacio Bonillas}

The genus Lambdotherium is well represented in fossil vertebrate collections from Wyoming. Indeed, it is an important index fossil for the Lost Cabin zone in the continental Eocene of North America; but, curiously enough, a complete dentition belonging to a single individual never has been recorded. The description of such a specimen, therefore, seems worthy of record, particularly since the material reveals some important characters that hitherto were uncertain or unknown.

Occurrence-In the vicinity of Tulsa, Wyoming, is exposed the upper part of a series of predominantly red-colored, continental deposits representing the Lost Cabin horizon, and overlain conformably by the Green River shales. These beds are exposed best along the Green River and for a limited distance along the banks of its tributaries. No stratigraphic break appears to exist within the section. The practically complete dentition of an individual of the genus Lambdotherium was found about 50 feet below the Green River shales at a point 6 miles north of the Sublette County line and one-half mile west of the Green River. Astragali, a calcaneus, broken vertebrae, and fragments of girdle and limb bones were found associated with the teeth. Scattered teeth of Lambdotherium were found elsewhere in the section, together with Eohippus, Meniscotherium, Coryphodon, Hyopsodus, Heptodon, a tarsiid primate, and a taeniodont.

Description of Material.-Dental formula: $\frac{3}{3}, \frac{1}{1}, \frac{3}{4}, \frac{3}{3}$. The upper incisors in specimen no. 1743, C. I. T. Vert. Paleo. Coll., figures 1 and 2, are chisel-shaped, semi-spatulate, slightly procumbent, and are arranged to form a semicircular or parabolic curve. The upper canines are sharply pointed, and of a round-oval base, being slightly compressed laterally. A diastema is present between $\mathrm{I}^{3}$ and the canine, and also between the canine and $\mathrm{P}^{1}$. The first premolar has not been recorded previously, leading to the belief that it is absent in Lambdotherium. In specimen no. 1743, this tooth is two-rooted, with a simple, single-cusped, laterally compressed crown. The presence of two roots contradicts the belief that this tooth was absent in any individual of the genus. $\mathrm{P}^{2}$ is threerooted, with the crown somewhat extended anteriorly. A postero-internal protocone, a faint metacone, and an external cingulum are present. $\mathrm{P}^{3}$ has a very prominent protocone from which two cross-lophs, bearing accessory cuspules, lead to the paracone and metacone. The latter cusps are of equal size. A strong parastyle is present, but the mesostyle is of incipient size, although distinct. $\mathrm{P}^{4}$ is similar to $\mathrm{P}^{3}$, except that the characters are more strongly marked. In this tooth a strong parastyle and mesostyle are present, the cross-lophs and accessory cusps are more prominent, and an internal cingulum is well developed. The molars resemble each other very closely. All have the characteristic oblique, W-shaped ectoloph and a very strong parastyle and mesostyle. The principal cusps are the protocone, metacone, paracone, and hypocone, and the protoconule is fairly large and slightly crescentic. The metaloph is low; the metaconule not distinct. Intermediate styles or buttresses are present on the ectoloph opposite the protocone, and are weakly developed opposite the metacone. The internal cingulum is variably developed, being absent entirely on some molars and fairly strong on others. 
The jaw is slender and elongate, not so deep in proportion to length as in some specimens figured by Osborn. A very pronounced diastema intervenes between the canine

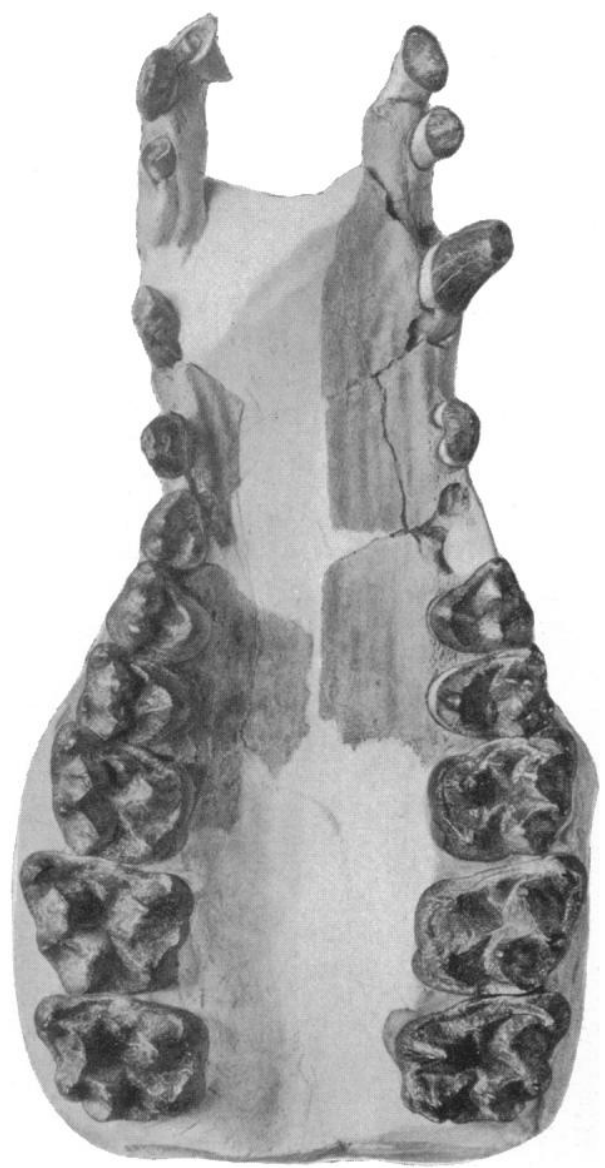

FIG. 1

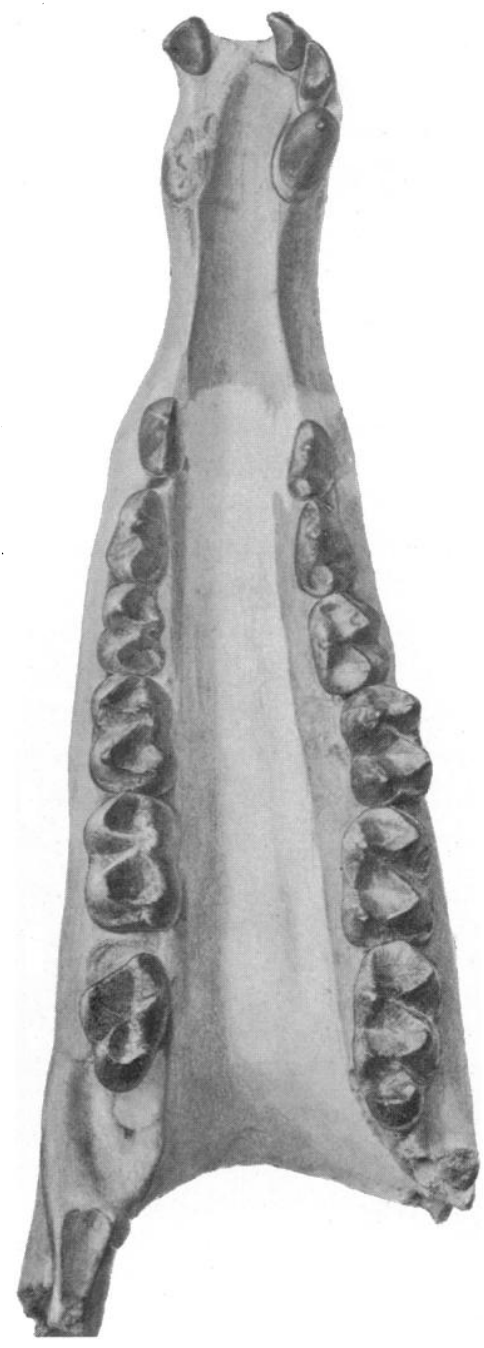

Fig. 2

\section{Lambdotherium popoagicum Cope}

Figure 1, palate with upper dentition. Figure 2, mandible with lower dentition; no. 1743 Calif. Inst. Tech. Vert. Paleo. Coll.; occlusal views, $\times 1$. Lost Cabin Beds, Lower Eocene; Tulsa, Wyoming.

and $\mathrm{P}_{2}$, the chin being extended at the symphysis. The lower incisors are quite spatulate and chisel-shaped, and have a semicircular arrangement. The lower canines, like 
the uppers, are sharply pointed, slightly recurved, and laterally compressed. The first lower premolar, as previously demonstrated, definitely is absent. The second premolar is rather simple, consisting of a large protoconid with small paraconid and hypoconid. In $\mathrm{P}_{3}$ the metaconid is distinct, although very small; the paraconid is stronger, as also is the hypoconid. The fourth premolar is completely molariform, save for the absence of an entoconid. The molars are quite lophiodont, consisting of protoconid, metastylid and metaconid, hypoconid, and entoconid. A rudimentary talonid is present in the first two molars, and is expanded into a strong crescentic cusp in the third molar.

COMPaRATIVE MEASUREMENTS (IN MiLlimeters)

\begin{tabular}{|c|c|c|c|c|c|}
\hline & $\begin{array}{l}\text { L. popo- } \\
\text { agicum } \\
\text { No. } 1743 \\
\text { C.I.T. }\end{array}$ & $\begin{array}{l}\text { L. popo- } \\
\text { agicum } \\
\text { Type, } \\
\text { No.4863 } \\
\text { A.M.N.H }\end{array}$ & $\begin{array}{c}\text { L. mag- } \\
\text { num } \\
\text { Type, } \\
\text { No. } 17527 \\
\text { A.M.N.H. }\end{array}$ & & \\
\hline $\mathbf{P}_{2}-\mathbf{M}_{3} \ldots$ & .72 .4 & 68.7 & 74 & $\mathrm{M}^{1}-\mathrm{M}^{3} \ldots \ldots \ldots 40.6$ & $36-34$ \\
\hline $\mathrm{M}_{1}-\mathrm{M}_{3} \ldots$ & 45.1 & 42 & 44 & $\mathbf{P}^{1} \ldots \ldots \ldots \ldots 6.6$ & \\
\hline $\mathbf{P}_{2} \ldots \ldots$ & 8.4 & 7.5 & 8.5 & $\mathbf{P}^{2} \ldots \ldots \ldots \ldots 8.3$ & 7 \\
\hline $\mathbf{P}_{3} \ldots \ldots \ldots \ldots$ & . 9.5 & 9.3 & 9.5 & $\mathbf{P}^{3} \ldots \ldots \ldots \ldots \quad 9.4$ & $7-7.8$ \\
\hline $\mathbf{P}_{4} \ldots \ldots \ldots \ldots$ & 9.9 & 9.4 & 10.0 & $P^{4} \ldots \ldots \ldots \ldots 10.0$ & $8-8.5$ \\
\hline $\mathbf{M}_{1} \ldots \ldots$ & .12 .5 & 11.4 & 12 & $\ldots 13.3$ & $10.3-11.5$ \\
\hline $\mathbf{M}_{2} \ldots \ldots \ldots \ldots$ & . 13.7 & 12 & 13 & $\mathbf{M}^{2} \ldots \ldots$ & $10.9-12.0$ \\
\hline $\mathrm{M}_{3} \ldots \ldots \ldots \ldots$ & 18.4 & 17.5 & 18.5 & $\mathrm{M}^{3} \ldots \ldots \ldots \ldots 13.2$ & $11.4-12.0$ \\
\hline Diastema..... & 23.7 & & & $\begin{array}{l}\text { Diastema, } \\
\quad \mathrm{P}^{1}-\mathrm{C} \ldots \ldots \ldots 9.2\end{array}$ & \\
\hline $\begin{array}{c}\text { Depth of jaw } \\
\text { below } \\
\text { (hyd)........ }\end{array}$ & 24.8 & & & $\begin{array}{l}\text { Diastema } \\
\text { C-I } I^{3} \ldots \ldots \ldots\end{array}$ & \\
\hline $\begin{array}{l}\mathbf{P}^{1}-\mathbf{M}^{3} \ldots \ldots \ldots \\
\mathbf{P}^{2}-M^{3} \ldots \ldots \ldots\end{array}$ & $\begin{array}{l}73.3 \\
66.0\end{array}$ & 58.6 & & $\mathrm{M}^{1}-\mathrm{M}^{2} \ldots \ldots \ldots 27: 0$ & 25.0 \\
\hline
\end{tabular}

Comparisons and Conclusions.-Five species of Lambdotherium have been described; L. popoagicum, L. primaevum, L. priscum, L. progressum, and L. magnum. The primary basis for specific recognition within the genus is the degree of molarization of the lower premolars. Thus $L$. priscum Osborn has simple, $L$. popoagicum Cope intermediate, and L. progressum Osborn sub-molariform lower premolars. L. magnum Osborn has the same premolar development as $L$. popoagicum, but is distinguishable on the basis of size. Osborn (Bull. Amer. Mus. Nat. Hist., vol. 41, art. 15, p. 562, 1919) said, "These [lower] teeth exceed in length over all (.074) those of the type of $L$. popoagicum in which the same teeth measure .069". In specimen no. 1743, a similar measurement is .0725 , indicating a size intermediate between that of the above two forms. The difference in size does not appear to constitute a valid criterion for specific differentiation.

The type of $L$. primaevum Loomis is featured by a strong cingulum surrounding the individual upper molars, and by the presence of crescentic protoconules, a character shared with $L$. progressum. Because of the varied development of the cingula in the teeth of the Tulsa individual, the strength of the basal ledge may be regarded as an individual character. With only a slightly greater variation than occurs in this specimen, teeth referable to different species could be obtained from the same skull. For example, $M^{1}$ (left side) of the Tulsa specimen well might be considered a tooth of $L$. primaevum.

A succession of lower premolar series leading from $L$. priscum through $L$. popoagicum to $L$. progressum is shown in figure 3 . The Tulsa specimen (not lettered in figure) has the very rudimentary metaconid and paraconid on $\mathrm{P}_{3}$, characteristic of an individual of 
$L$. popoagicum, resembling closely $L$. priscum. But the upper teeth are very close to those of specimens referable to $L$. progressum, as figured by Osborn (ibid., figure 2). This resemblance to the latter is attested by the strong development of styles and crosslophs in $\mathrm{P}^{3}$ and $\mathrm{P}^{4}$ of specimen no. 1743. Thus the degree of molarization of the upper and lower premolars is an individual rather than a specific character.

The recognition within the genus Lambotherium of only one species, with fairly wide range of individual variation, is based on the following reasons; (1) all these forms occur at the same stratigraphic horizon within a narrow geologic zone, (2) the species $L$. priscum, $L$. popoagicum, and $L$. progressum merge into each other by insensible gradations,
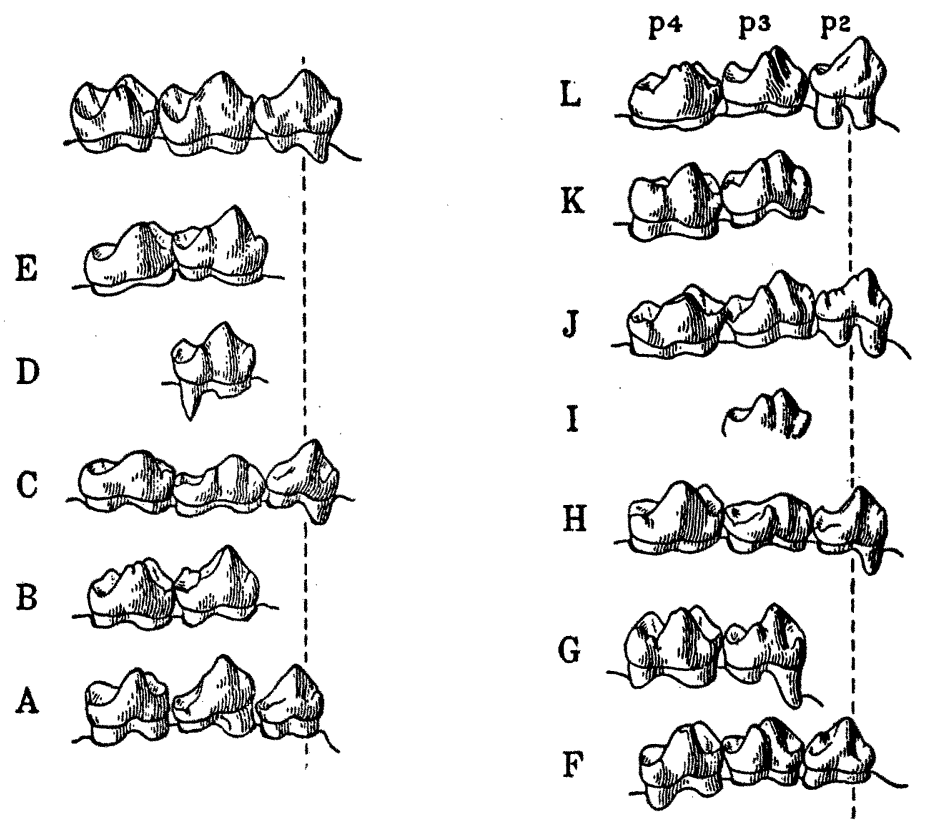

Fig. 3. Lower premolars of three "species" or mutations of Lambdotherium. Lettered figures after Osborn. Unlettered figure of specimen no. 1743 C.I.T. Coll. Vert. Paleo. from Tulsa, Wyoming. Natural size.

(3) the upper and lower dentition of the Tulsa specimen shows characters which individually have been regarded as featuring particular species of Lambdotherium, (4) it also is of such size as to indicate a gradation from $L$. magnum to $L$. popoagicum, and (5) it has a varied development of the cingulum, the strength of which is the principal character of $L$. primaevum.

The Tulsa individual, as well as all others of the genus, should be referred to $L$. popoagicum. Not only was this the first species described, but its characters are fairly intermediate between the extremes of individual variation.

Balch Graduate School of the Geological Sciences (Contribution no. 176), California Institute of Technology, Pasadena, California. 